\title{
An Analysis of Cross-Border Mergers and Acquisitions' Effects on China's Automotive Industry Security and the Countermeasures
}

\author{
Jianhong Huang \\ College of Tourism, Hainan University \\ Haikou 570228, China \\ Tel: 86-898-6625-8711 E-mail: yanhuang3721@yahoo.com.cn
}

This paper is funded by China Soft Science Program (2008GXQ6D170) and Hainan Key Science and Technology Program (080221).

\begin{abstract}
Along with the opening up of China economy, cross-border mergers and acquisitions exert a greater effect on China's industrial security. This paper is chiefly to discuss the influences of cross-border mergers and acquisitions on China automotive industry security. Based on convincible investigations and researches, this paper analyzes China automotive industry's domestic demand conditions, self problems, and cross-border mergers and acquisitions' influences on the industry, and advances relevant countermeasures and suggestions for improving China automotive industry security.
\end{abstract}

Keywords: Industrial security, Cross-border mergers and acquisitions, Automotive industry

In order to further study the impacts of cross-border mergers and acquisitions on China automotive industry and get more real data, the author collects useful information from China Statistical Yearbook, World Competitiveness Yearbook, The Yearbook of World Trade, and China Automotive Industry Yearbook published in recent years, and analyzes the problems of China automotive industry and cross- border mergers and acquisitions' impacts on the industry.

\section{The domestic demand and the tendency of China automotive industry}

China has already established the target of building up a comprehensive well-off society at the first twenty years in the new century. In 2020, GDP will be twice of that in 2000, reaching 4000 billion US dollars. At present, the western development program, the old industrial bases revitalizing, and newly issued a series of measures and suggestions for industrial structure upgrade will help to exert regional and industrial comparative advantages, shorten the economic gab between the east and the west, drive the healthy and harmonious development of national economy, promote the harmonious and fast growth of industry, what will undoubtedly bring about the fast rise of automobile demand. Meanwhile, the state adopts a series of effective measures and policies that aims at increasing farmers' income. To improve people's living level can also lead to the rise of consumption.

On May $7^{\text {th }}, 2007$, Organisation Internationale des Constructeurs d'Automobiles (OICA) publicized the statistical data of 2006 automobile output. Data show that Japan's automobile output surpasses America's in 2006 again, reaching $11,480,000$ automobiles, increasing $6.3 \%$ than that in 2005 (the output is 10,800,000 automobiles in 2005). China's automobile output is 7,190,000 in 2006, far exceeding than German's 5,820,000 automobiles. China has already become the third automobile production country in the world. In 2006, China's automobile output realizes a $25.0 \%$ rise than 2005. In 2005, China's automobile output is 5,710,000. In 2006, China's automobile output has become the No.3 in the world. If China's automotive industry develops at this rate, till 2010 China's automobile output will be No. 1 in the world.

Along with the economic development and urbanization process, consumers like pretty, comfortable, safe, economical, environment-friendly, and energy-saving automobiles. Noticeably, the proportion of cars to automobiles keeps in rising. 
In 2005 , the proportion is $48.49 \%$. In 2006, the number becomes $53.1 \%$, rising $4.66 \%$. Meanwhile, the proportion of small displacement car is rising quickly. Based on the automobile market conditions in recent five years, the Development Research Center of the State Council makes a prediction for China's automobile market demand: in 2010, the total automobile ownership will reach 59,380,000 and the total automobile demand 9,370,000. China will become the largest consumer for automobiles in the world.

\section{Problems in China's automotive industry}

\subsection{Few independent brands}

China's five big automobile groups have cooperated with foreign enterprises to a different degree. A lot of automobiles produced by them are marked with foreign brands. Their international competitiveness is not completely based on independent brands. For example, First Automobile Works' 300,000 Volkswagen, Tianjin First Automobile Works, Shanghai Automotive Industry Cooperation's (Group) 400,000 Volkswagen, Shanghai General Motor's 170,000 vehicles, Dongfeng Motor Cooperation's Fengshen Automobile, Chana Automobile Cooperation's Ford, Beijing Automobile Works' Hyundai and Cherokee are respectively from Volkswagen, General Motor, Ford, Toyota, Nissan, and Hyundai. By means of cooperation, China's five big automobile groups become a part of world ten automobile groups.

Till late 2005, China has 355 brands for trucks, passenger vehicles, and cars totally. Therein, $69 \%$ of brands are independent, and $31 \%$ foreign brands. But among 100 brands for cars, only 37 brands are independent. As for cars sold in domestic market, the foreign brands in joint production account for $90 \%$ of the market share.

According to the market data from Jan. to May in 2006, only Chery, Charade, and Geely belong to independent brands among the top ten brands. Other seven are joint brands. The seven joint brands account for $51.18 \%$ of market share.

\subsection{Lower industrial concentration}

China automobile production enterprises are small in general. In 2004, China has 117 automobile production enterprises. Therein, 23 enterprises realize an annual output less than 100 automobiles. Only 12 enterprises can achieve the annual output above 100,000 automobiles. Most automobile production enterprises do not reach the minimum and optimal scale economic level. In 2006, General Motor's world output is about 9,200,000 automobiles. China's total output is 7,190,000 automobiles, being 78\% of General Motor's output in 2006. In China automobile market, the market concentration of First Automobile Works, Shanghai Automotive Industry Cooperation and Chana Automobile Cooperation is $47.8 \%$. In contrast, the market concentration of American and Japan top three automobile enterprises reaches $70 \%$ above. Lower concentration is not good for the economy of scale, which may lead to high unit production costs and separate competition.

\subsection{Weak $R \& D$}

Compared with the country with developed automotive industry, the research and development capability of China's automotive industry is weak. It is still at an imitation stage. Especially for the car, there is no product with independent property right. All relevant technologies or designs are imported from foreign countries or jointly produced with foreign large enterprises. Usually, we use the R\&D performance index, namely the ratio $R$ of an enterprise's investment in $R \& D$ to sales, to evaluate an enterprise's view toward R\&D. This index takes the maximum $1.9 \%$ in 2004 as the critical value. Before, it has ever reached $1.38 \%$. After 2005, it fluctuates around 1.4\%. In general, in China the average rate of R\&D to sales is $1.5 \%$. The number is always $3.5 \%$ or so in developed countries. It proves that China automotive industry's investment in $\mathrm{R} \& \mathrm{D}$ is far less than other countries with developed automotive industry.

\subsection{Lagged-behind industrial management}

Generally speaking, the automotive industrial management is still at a lower level. It faces lots of serious problems. The multiple introduction leads to the fact that the industry has been controlled by trans-national companies. The industrial separation caused by multiple joint investments makes China's automotive industry face a demanding difficulty in structure adjustment. Indeed, by means of joint investment and technology introduction, China's automobile enterprises improve their management and operation level to certain degree. However, domestic automobile enterprises' management system, supply and purchase system, quality system, and personnel mechanism still lag behind the transnational companies. China's automobile enterprises still face problems of rigidified management system and low efficiency.

\section{The main impacts of cross-border mergers and acquisitions on China's automotive industry security}

\subsection{Strong technological dependence on foreign countries}

After more than twenty years' joint cooperation, China's automotive manufacturing industry shows its prosperity. But the absence of key technology brings more profits away. What's more seriously, some experts point out that once the market opens completely, foreign partners may get rid of Chinese partners who do not master core technologies. 
Formerly, Shanghai and Changchun automobile enterprises have had the automobile production competence and R\&D team. However, in order to introduce the Volkswagen from Germany, they gave up their independent brands, R\&D teams, and research platforms. So, they purchase a set of production line and produce a series of automobiles. Then, they purchase a new set of production line and produce a new series of automobiles. As a result, China loses the automobile production technologies and competence. Consequently, 90\% domestic automobile market has been occupied by trans-national companies. The market occupation ratio is decreasing. China's automobile enterprises fail to inherit original technologies on one hand. On the other hand, they can not master the brand-new core technologies, becoming a complete dependent industry. The high technological dependence on others reflects that the general development level of industrial technologies is still low. Besides, in China the consciousness of "focusing on the cultivation of innovative competence" and "guaranteeing innovators' rights" is still weak. The cultivation of innovative competence needs the official support. The government should encourage enterprises to absorb and consume foreign advanced technologies and drive the cultivation of innovative competence by arranging innovation tasks, changing the comprehensive dependence on foreign advanced technologies.

\subsection{Serious foreign fund holding}

In 2003, in the cooperation between Nissan and Dongfeng, foreign funds have already reached the top limit $50 \%$. German Volkswagen invests more in Shanghai Volkswagen and FAW Volkswagen. USA General Motor and Daimler Chrysler increase the investments in their joint enterprises respectively. Japan Honda cooperates with Chinese partners and form Honda Automobile (China) cooperation, in which the proportion of registered foreign funds have reached $65 \%$. During the development of China automobile market, trans-national automobile companies realize their strategic allocation in China by joint-venture and investment. Now, they tend to control the future development of China automotive industry. In the passenger vehicle field that has the greatest potential, it has already formed an industrial development pattern dominated by trans-national companies. The commercial vehicle field also faces trans-national companies' strong penetration at present. In the automotive industry, the rate of foreign fund holding is $21.8 \%$. Therein, the rate in automobile parts enterprises is higher than that in automobile makers.

\subsection{The fact that foreign funds control the operation and decision tends to be more serious.}

Generally speaking, as joint partners, each side can arrange a chief in every branch. They enjoy equal rights. Key decisions should be made by both sides. In the technology, production, purchase, and finance aspect, the foreign partner has more words. As for the personnel, market, and sales, the Chinese partner has more words. Due to the control over technology, the foreign partner has mastered the right of controlling R\&D in the joint venture. A report says that Beijing Hyundai's Korea boarders have already controlled three key branches: R\&D, purchase, and sales. As for the sales net, in April 2007, Shaoge Wu, the former senior market manager in Volkswagen (China), replaced Feng Wang in First Automobile Works. Besides, along with the popularization of power-concentrated vertical management mode, the re-programming of sales areas, and the channel reform, Volkswagen successfully controls the First Automobile Works' sales channels in a year. As a matter of fact, First Automobile Works is becoming the "producing shop" of Volkswagen in China. By turning the production-sales separation into the production-sales combination in joint ventures, foreign funds are improving their control over the sales net.

\section{Suggestions for improving China's automotive industry security}

\subsection{Strengthen $R \& D$}

Although many large enterprises accumulate some useful experiences for independent R\&D along with the fast development of automotive industry in recent years, China's automotive industry still depends on trans-national companies at present, which is determined by the nature of automotive industry: high risks and lagged-behind returns. China's automotive industry does possess any advantage in high value added field, such as R\&D, marketing, and brands. The only advantage is the low cost. Therefore, they merely produce some low-grade automobiles. If China's automobile enterprises hope to display their competitive advantages, they must cultivate their own brands and develop new products. Here, the government should offer a complete support, constructing a brand-new technological innovation platform.

In a short period, we can concentrate all technology innovation resources and competence, depend on a brand-new technological platform, and form a positive interaction with the development of automotive industry, driving the automotive industry development. For a long period, we can make best use of the effective operation mechanism and form the innovative competence in key products and technologies, realizing an essential improvement of the automotive industry. For an instance, we should emphasize on the development of new energies and technologies, solving the energy-saving and environment issue. At present, automobiles are mainly fueled by gasoline and diesel. Because the shortage of world oil resources, the development of new energies for automobiles tends to be urgent. The widely accepted best substitute energy is fuel cell. It takes the hydrogen as the energy. The emission is water. Hydrogen can be got from water. Electric power is from wind energy, solar energy, or water energy. However, the high cost of fuel cell 
makes it difficult to popularize it in a short period. Therefore, presently many countries' automotive industry is trying to develop the fuel cell technology or research other new technologies. China's automotive industry is not an exception. Soon, new relevant product will appear in China.

\subsection{Cancel the super national treatment for trans-national companies}

All kinds of automobile enterprises should enjoy equal treatments. The super national treatment is an important factor impacting China's automotive industry development. No matter what it is the industry opening or preferential policy, all enterprises should be equal. Where the trans-national company can enter, domestic private enterprises can enter either. However, even for some large private enterprises, they are not allowed to enter the automotive industry. Besides, the preferential policies in land requisition and taxation should be made for both trans-national companies and domestic enterprises. Otherwise, it will lead to serious negative effects. The society may question the policy and resources could not be distributed reasonably.

Trans-national companies can enjoy the national treatment, what is accepted by Chinese consumers. In a national treatment environment, trans-national companies can compete with other enterprises equally, which will really improve companies' vitality and competitiveness. To cancel the super national treatment will benefit the benign development of China's national economy.

\subsection{Perfect the Anti-Monopoly Law and relevant market laws and regulations}

In dealing with the monopoly position of trans-national companies in China, China should perfect the Anti-Monopoly Law and relevant market laws and regulations, and construct an effective anti- monopoly legal system, beating the monopoly activities, especially the price monopoly. Besides, set up special anti-monopoly executive institutions that are independent from common administrative agencies, perfecting the anti-monopoly system, and guaranteeing the implementation of Anti-Monopoly Law.

\subsection{Set up a dumping recognition system}

Since the operation of China industrial pre-warning system in 2002, some auto parts are in yellow warning. Just as what was said by Qinhua Wang, a former officer in the Ministry of Commerce of PRC: "Auto parts suffer more serious monopoly threat than whole vehicles. They may face dumping." Then, it is urgent to construct a perfect dumping recognition system. In 2008, China starts the anti-dumping for key auto parts enterprises, including Bosch and Delphi. It shows China's concerns for the security of domestic enterprises. The anti-dumping recognition system should possess three functions at least: whether it is anti-dumping activity, what the harm to the industry will be if no anti-dumping, and how to take ensured and compensation measures.

\subsection{Enhance the cooperation between enterprises}

No matter what it is the whole vehicle manufacturing enterprise or auto parts enterprise, they should take references from foreign experiences in R\&D, production, and sales field. Different enterprises can share a common R\&D platform, breaking the technology bottle-net by cooperation, and defending foreign enterprises' technological restricts. However, this kind of cooperation between domestic enterprises is few. We should encourage enterprises to realize a mutual cooperation. How to protect self and win more time for development by means of trade in local market under the WTO principles will turn into the new subject for China's automotive industry.

\section{References}

Gui, Shouping, Lu, Aihua \& Lu, Lifang. (2007). The impact of auto manufacturing industrial chain correlative effect on regional economy. Commercial Research, No.8.

He, Lin. (2005). Analysis of international competitive capacity of auto industry in our country. Forecasting, No.2.

Kang, Zanliang \& Liu, Haiyun. (2006). An empirical analysis of China automobile market supply elasticity and demand elasticity. Statistics and Decision, No.3.

Liu, Manfeng. (2005). The DEA model for estimating the auto industry security after the WTO entry. Statistics and Decision, No.1.

Peng, Xie. (2006). Powers of technology explains the competence of communication facilities, computer and other electric equipment production industries. China Quality Daily, No.5. 